\title{
PENEGAKAN HUKUM TERHADAP PELANGGARAN HAK MEREK DI KOTA MAKASSAR
}

\author{
St. Nurjannah \\ Universitas Islam Negeri Alauddin Makassar \\ Email: stnurjannahuinam@gmail.com
}

\begin{abstract}
The form of law enforcement against brand violations in the city of Makassar has been regulated in Law No. 20 of 2016 that has been good and perfect because it has gone through several revisions and in practice, law enforcement against these violations has been carried out well by investigators of the civil service Ministry of Law and Human Rights who work closely with the Republic of Indonesia National Police investigators and Public Prosecutors. But it is needed addition to the number of civil servant investigators in the scope of ministries that specifically deal with violations of brand rights and IPR as a whole so that enforcement and implementation of the Law / 20 of 2016 is more maximal. The stipulation of laws concerning brands which constitute complaint offenses must be changed to the usual offense of enforcement of violations of Brand Rights which can be immediately processed by the authorities without waiting for a complaint.
\end{abstract}

Key Words: Law Enforcement, Brand Rights

\begin{abstract}
Abstrak
Bentuk penegakan hukum terhadap pelanggaran merek di kota Makassar telah diatur didalam UU No. 20 Tahun 2016 yang telah bagus dan sempurna karena telah melalui beberapakali revisi dan dalam prakteknya, penegakan hukum terhadap pelanggaran ini telah dijalankan dengan baik oleh penyidik pegawai negeri sipil kementerian Hukum dan Ham yang berkerja sama dengan penyidik Kepolisian Negara republik Indonesia serta Penuntut Umum. Namun, diperlukan penambahan jumlah penyidik pegawai negeri sipil dilingkup kementrian yang khusus menangani pelanggaran hak merek dan HKI secara keseluruhan agar penegakan dan penerapan UU/20 tahun 2016 lebih maksimal. Penetapan UU tentang merek yang merupakan delik aduan harus diubah menjadi delik biasa sehingga penegakan terhadap pelanggaran Hak Merek dapat segera diproses oleh pihak yang berwajib tanpa menunggu adanya aduan.
\end{abstract}

Kata Kunci: Penegakan Hukum, Hak Merek 


\section{PENDAHULUAN}

Istilah HKI sebelumnya bernama Hak Milik Intelektual yang selama ini digunakan. Menurut Bambang Kesowo, istilah Hak Milik Intelektual belum menggambarkan unsur-unsur pokok yang membentuk pengertian Intellectual Property Right, yaitu hak kekayaan dari kemampuan intelektual. Istilah Hak Milik Intelektual (HMI) masih banyak digunakan karena dianggap logis untuk memilih langkah yang konsisten dalam kerangka berfikir yuridis normatif. Istilah HMI ini bersumber pada konsepsi Hak Milik Kebendaan yang tercamtum pada KUHPerdata Pasal 499, 501, 502, 503, 504.

Pasca ratifikasi WTO/TRIPs Agreement hingga sekarang, di Indonesia bidang- bidang HKI yang telah diatur dalam undang-undang adalah: UndangUndang Nomor 28 tahun 2014 tentang Hak Cipta, Undang-Undang Nomor 14 Tahun 2001 tentang Paten, Undang-Undang Nomor 15 Tahun 2001 tentang Merek, Indikasi geografis dan indikasi asal termasuk juga diatur dalam undang-undang ini, Undang-Undang Nomor 30 Tahun 2000 tentang Rahasia Dagang, Undang-Undang Nomor 29 Tahun 2000 tentang Perlindungan Varietas Tanaman, Undang-Undang Nomor 31 Tahun 2000 tentang Desain Industri, dan Undang-Undang Nomor 32 Tahun 2000 tentang Desain Tata Letak Sirkuit Terpadu. ${ }^{4}$

Pengenalan HKI sebagai hak milik perorangan yang tidak berwujud dan penjabarannya secara lugas dalam tatanan hukum positif terutama dalam kehidupan ekonomi merupakan hal baru di Indonesia. Dari sudut pandang HKI, aturan tersebut

diperlukan karena adanya sikap penghargaan, penghormatan dan perlindungan tidak saja akan memberikan rasa aman, tetapi juga mewujudkan iklim yang kondusif bagi peningkatan semangat atau gairah untuk menghasilkan karyakarya inovatif, inventif dan produktif. Pelanggaran Hak Kekayaan Intelektual (HKI) seperti pembajakan, pemalsuan, peniruan, pemanfaatan hak kekayaan intelektual tanpa izin sering diidentikkan dengan perilaku kriminal karena adanya kerugian secara ekonomi.

Indonesia merupakan salah satu negara yang menjadi sasaran pangsa pasar dunia. Hal ini menyebabkan Indonesia menjadi negara yang sangat rawan terjadi pelanggaran di bidang perindustrian. contohnya Pelanggaran Hak Merek khusunya di Kota Makassar..Hal ini terlihat dengan banyaknya produkproduk tiruan merek ternama antara lain baju, sepatu, jam tangan dan produk fashion lainnya, yang beredar luas dipasaran dengan harga dan kualitas yang berbeda. Tingkat pelanggaran Hak Kekayaan Intelektual (HKI) yang tiap tahun selalu meningkat.

Dengan tingginya kegiatan pelanggaran HKI di kota Makasar khusunya 
pada pelanggaran hak merek. Hal ini tentunya tidak hanya merugikan para pengusahanya saja sebagai pemilik atau pemegang hak atas merek tersebut, tetapi juga bagi para konsumen. Pada fungsinya, merek memiliki kemampuan sebagai tanda yang dapat membedakan hasil perusahaan yang satu dengan perusahaan yang lain di dalam pasar, baik untuk barang/jasa yang sejenis maupun yang tidak sejenis. Fungsi merek tidak hanya sekedar untuk membedakan suatu produk dengan produk lain, melainkan juga berfungsi sebagai aset perusahaan yang tidak ternilai harganya, khususnya untuk merekmerek yang berpredikat terkenal( well-known marks).

Upaya pemilik merek untuk mencegah pemakaian mereknya oleh pihak lain merupakan hal yang sangat penting dan sepatutnya dilindungi oleh hukum. Berkaitan dengan perlindungan merek, perdagangan tidak akan berkembang jika merek tidak mendapat perlindungan hukum yang memadai di suatu Negara. Sebuah merek dapat menimbulkan persaingan usaha tidak sehat karena melalui merek produk barang atau jasa sejenis dapat dibedakan asal muasalnya, kualitasnya serta keterjaminan bahwa suatu produk tersebut Original. Melalui merek sebuah perusahaan telah membangun suatu karakter terhadap produk-produknya, yang diharapkan akan dapat membentuk reputasi bisnis yang meningkat atas penggunaan merek tersebut. Untuk itu pemilik merek dapat mendaftarkan mereknya pada Dirjen HKI. Dengan mendaftar, pemilik merek akan terlindungi haknya.

\section{PEMBAHASAN}

\section{A. Perlindungan Hukum Hak Merek Terdaftar}

Konsep perlindungan terhadap HKI pada dasarnya adalah memberikan hak monopoli, dan dengan hak monopoli ini, pemilik HKI dapat menikmati manfaat ekonomi dari kekayaan intelektual yang didapatnya. Perlu diakui bahwa konsep HKI yang kita anut berasal dari Barat, yaitu konsep yang didasarkan atas kemampuan individual dalam melakukan kegiatan untuk menghasilkan temuan (invention). Pemberian hak monopoli kepada individu dan perusahaan ini, sering bertentangan dengan kepentingan publik (obat, makanan, pertanian). Di samping itu, berbagai perundangan HKI pada kenyataannya tidak dapat melindungi pengetahuan dan kearifan tradisional (traditional knowledge and genius). Pengetahuan tradisional yang berkembang di negara seperti Indonesia, berorientasi kepada komunitas, bukan individu. Sehingga masalah perlindungan pengetahuan tradisional yang muncul selalu harus diselesaikan secara khusus (obat, herbs, lingkungan hidup). Dimasukannya masalah HKI 
kedalam bagian dari GATT melalui TRIPS, menambah kesenjangan dalam pemanfaatan kekayaan intelektual antara negara maju dan negara industri baru/berkembang.

HKI dibangun di atas landasan "kepentingan ekonomi", hukum tentang property (intellectual property). HKI identik dengan komersialisasi karya intelektual sebagai suatu property. Perlindungan HKI menjadi tidak relevan apabila tidak dikaitkan dengan proses atau kegiatan komersialisasi HKI itu sendiri. Hal ini makin jelas dengan munculnya istilah "Trade Related Aspect of Intellectual Property Rights" (TRIPs), dalam kaitannya dengan masalah perdagangan internasional dan menjadi sebuah icon penting dalam pembicaraan tentang karya intelektual manusia. Ini pun berarti bahwa HKI lebih menjadi domainnya GATT-WTO, ketimbang WIPO. Karakter dasar HKI semacam itulah yang diadopsi ke dalam perundang-undangan Indonesia. Dapat dikatakan bahwa pembentukan hukum HKI di Indonesia merupakan transplantasi hukum asing ke dalam sistem hukum Indonesia.

Dalam perlindungan hukum terhadap hak merek dikenal dengan perlindungan hukum preventif. Pengertian perlindungan hukum represif adalah perlindungan yang dilakukan untuk menyelesaikan atau menanggulangi suatu peristiwa atau kejadian yang terjadi, yaitu berupa pelanggaran hak atas merek. Tentunya dengan demikian peranan lebih besar berada pada lembaga peradilan dan aparat penegak hukum lainnya seperti Kepolisian, Pejabat Pegawai Negeri Sipil (PPNS), dan Kejaksaan untuk melakukan penindakan terhadap pelanggaran merek. Dalam perlindungan hukum yang sifatnya represif, maka pemberian sanksi yang jelas dan tegas bagi pelaku pelanggaran merek sesuai dengan UndangUndang Merek yang berlaku, juga harus dilaksanakan oleh aparat penegak hukum secara konsisten. Ini akan memberikan jaminan kepastian hukum khususnya bagi pemegang hak atas merek dagang terkenal asing di Indonesia. ${ }^{18}$ Faktor-faktor yang harus diperhatikan dalam upaya preventif adalah: 19

a. Faktor hukum

Undang-Undang No. 15 Tahun 2001 bertujuan untuk lebih memberikan perlindungan hukum bagi pemegang hak atas merek dagang terkenal asing.

b. Faktor aparat Direktorat Jendral HKI

Aparat Direktorat Merek, Direktorat Jenderal HKI bertugas untuk memeriksa permohonan pendaftaran merek. Hal yang paling mendasar yang perlu dicermati oleh aparat Direktorat Merek yaitu: 20

1) Terjadinya pendaftaran suatu merek tertentu yang sama dan menyerupai dengan merek terkenal milik pihak lain dapat terjadi, 
salah satunya disebabkan kelemahan dari aparat Direktorat Merek dalam melakukan proses filterisasi di awal pengajuan merek tersebut oleh masyarakat.

2) Penguasaan bahasa asing di lingkungan aparat Direktorat Merek perlu terus ditingkatkan, persoalan ini menjadi problematika tersendiri ketika dilakukan pemeriksaan merek, penguasaan teknologi di era sekarang ini juga harus menjadi bahan perhatian serius Direktorat Merek seperti Penggunaan internet online kepada masyarakat tentunya sangat memudahkan bagi pihak yang ingin melakukan pendaftaran merek untuk segera dapat mengetahui apakah merek yang akan didaftarkannya tersebut telah dimiliki oleh pihak lain atau belum.

Dalam hal ini, HKI sangat potensial untuk menjadi objek sengketa dengan melibatkan para pihak yang berbeda lokasi dan berbeda pula hukumnya. Karena itu patut di cermati penegakan hukum sebagai salah satu konsekuensi HKI sebagai objek kekayaan yang memberikan kewenangan untuk menetukan siapa yang boleh memperoleh kreasi intelektualnya yang pada dasarnya ada asumsi hak (right), kewajiban (obligation) dan keistimewaan (prevelege) dari HKI bersifat absolute dan universal. 21

Pemegang HKI berhak untuk secara bebas mengontrol HKInya dengan menggunakan perjanjian yang bersifat pribadi dan menetapkan sebagai persyaratan bagi siapa pun yang bermaksud memanfaatkan kreasi intelektualnya. Untuk itu, apabila HKI di batasi, maka pencipta, inventor atau pendesainnya harus mendapatkan konpensasi yang layak, misalnya jika HKInya di bebani lisensi wajib ataupun HKInya diambil untuk kepentingan Negara. Demikian halnya jika pihak lain, selain pemegang HKI menikmati kegunaan karya intelektual tersebut, maka konpensasi yang layak harus di dasar pembelaan pihak lain untuk mempermasalahkan kebebasan HKI. ${ }^{22}$

Dalam perlindungan yang diberikan oleh Jenderal HKI tentu saja hanya kepada merek yang telah terdaftar. Perlindungan terhadap merek-merek yang telah terdaftar telah jelas terlindungi menurut Undang-undang Hak cipta No. 20 tahun 2016. Sementara merek yang tidak terdaftar di Dirjen HKI, tidak akan mendapatkan perlindungan. Maka sangat penting bagi setiap merek untuk didaftarkan agar mendapatkan perlindungan hukum.

\section{B. Ketentuan Hukum Terhadap perlindungan Hak Merek Terdaftar \\ 1) Ketentuan Pidana \\ Dalam ketentuan pidana undang-undang merek telah memberikan}


ancaman pidana kepada setiap oaring yang menggunakan merek yang sama pada keseluruhannya ataupun yang sama pada pokoknya. Kedua bentuk perbuatan ini diklasifikasikan sebagai kejahatan. Besarnya ancaman ditemukan dalam pasal 90 dan 91, sebagaimana berikut. 23

a. Pasal 90 menyatakan bahwa, Barangsiapa dengan sengaja dan tanpa hak menggunakan Merek yang sama pada keseluruhannya dengan Merek terdaftar milik pihak lain untuk barang dan/atau jasa sejenis yang diproduksi dan/atau diperdagangkan, dipidana dengan pidana penjara paling lama 5 (lima) tahun dan/atau denda paling banyak Rp. 1.000.000.000,00 (satu miliar rupiah).

b. Pasal 91 menyatakan bahwa, Barangsiapa dengan sengaja dan tanpa hak menggunakan Merek yang sama pada pokoknya dengan Merek terdaftar milik pihak lain untuk barang dan/atau jasa sejenis yang diproduksi dan/atau diperdagangkan, dipidana dengan pidana penjara paling lama 4 (empat) tahun dan/atau denda paling banyak Rp. 800.000.000,00 (delapan ratus juta rupiah).

Adapun bagi mereka yang memperdagangkan barang dan/atau jasa yang diketahui atau patut diketahui bahwa barang dan/atau jasa tersebut merupakan hasil pelanggaran sebagaimana dimaksud dalam Pasal 90, Pasal 91, Pasal 92, dan Pasal 93 dipidana dengan pidana kurungan paling lama 1 (satu) tahun atau denda paling banyak Rp. 200.000.000,00 (dua ratus juta rupiah) (pasal 94 ayat 1). Tidak pidana ini adalah pelanggaran. Tindak pidana sebagaimana yang dimaksud dalam pasal 90, pasal 91, dan pasal 94 merupakan delik aduan.

2) Ketentuan Perdata

Pasal 76 ayat 1 huruf a menyatakan bahwa Pemilik merek terdaftar dapat mengajukan gugatan terhadap pihak lain yang secara tanpa hak menggunakan merek yang mempunyai persamaan pada pokoknya atau keseluruhannya untuk barang atau jasa yang sejenis berupa gugatan ganti rugi.

Pasal 76 ayat 1 huruf b menyatakan bahwa pemilik merek terdaftar dapat mengajukan gugatan pada pihak lain yang secara tanpa hak menggunakan merek yang mempunyai persamaan pada pokoknya atau keseluruhannya untuk barang atau jasa yang sejenis berupa penghentian semua perbuatan yang berkaitan dengan penggunaan merek tersebut. Seluruh gugatan ditunjukan kepada Pengadilan Niaga. Hak Merek merupakan suatu hak kebendaan, oleh karena haknya bersifat kebendaan maka hak tersebut dapat dipertahankan oleh siapa saja. Di dalam Pasal 76 tersebut disebutkan ada dua macam bentuk dari tuntutan gugatan yakni berupa permintaan ganti rugi dan penghentian dari pemakaian suatu merek. Ganti rugi tersebut harus dapat dinilai dengan uang, 
dan ganti rugi immaterial yakni berupa gantirugi yang disebabkan oleh pemakaian merek dengan tanpa hak sehingga yang berhak menderita kerugian secara moril.

3) Ketentuan Administrasi

Tindakan Administratif merupakan kewenangan yang di limpahkan pada Kantor merek yang dapat di kenakan pada setiap orang/badan Hukum yang melakukan pelanggaran terhadap hak merak, sesuai dengan kewenanganya Tindakan administratif yang dapat di lakukan oleh kantor Merek antara Lain:

a. Melakukan penolakan atas permintaan pendaftaran Merek. Pada tahap proses permintaan pendaftaran merek, Peranan Kantor Merek sangat menentukan dalam memberikan perlindungan hukum kepada pemilik merek yang sudah terdaftar. Dengan kewenangan yang di milikinya, kantor Merek berhak menolak permintaan pendaftaran.

b. Pengahapusan Pendaftaran Merek dari DUM ( Daftar Umum Merek). Dalam ketentuan pasal 61 ayat 1 undang - undang memberikan wewenang kepada kantor Merek secara " Ex officio" atau atas prakasa sendiri untuk mengambil tindakan administrasi, yakni melakukan penghapusan pendaftaran merek dari DUM ( Daftar Umum Merek). Tindakan penghapusan pendaftaran merek dapat dilakukan Kantor merek apabila diperoleh bukti yang cukup atas dasar alasan Bahwa merek yang digunakan tidak sesuai dengan yang didaftarkan.

Penegak hukum mempunyai ruang lingkup yang sangat luas karena mereka yang secara langsung maupun tidak langsung turut serta dalam proses penegakan hukum. Setiap penegak hukum mempunyai kedudukan dan peranan masing-masing. Dalam menjalankan peranan dan kedudukannya penegak hukum memiliki wewenang untuk melakukan sesuatu berdasarkan jabatannya. Apabila peraturan perundang-undangan sudah baik namun kalau penegak hukumnya tidak menjalankan tugasnya dengan baik maka akan menimbulkan efek yang tidak baik dalam sistem penegakan hukum.

\section{PENUTUP}

Penegakan hukum terhadap pelanggaran merek di kota Makassar telah diatur didalam UU No. 20 Tahun 2016 yang telah bagus dan sempurna karena telah melalui beberapakali revisi. Sementara dalam prakteknya, penegakan hukum terhadap pelanggaran ini telah dijalankan dengan baik oleh penyidik pegawai negeri sipil kementrian Hukum dan Ham yang berkerja sama 
dengan penyidik Kepolisian Negara Republik Indonesia serta Penuntut Umum. Namun karena UU No. 20 Tahun 2016 merupakan delik aduan yang membuat aparat penegak hukum tidak leluasa dalam membuat tuntutan. 


\section{DAFTAR PUSTAKA}

Chazawi, Adami.. Kejahatan Terhadap Pemalsuan. Jakarta: PT. Raja Grafindo

Erni Vika Qomaria, Penegakan Hukum Hak Merek Terhadap Pelanggaran Pada Pokoknya.

Universitas Wijaya Putra Surabaya, 2014

Faraz, Haedah, Perlindungan Hak Atas Merek, Jurnal Dinamika Hukum Vol.8No.1Januari2008. http://oaji.net/articles/2015/15701427171959.pdf diakses pada hari Sabtu,3 juni 2017. Pukul 15.20

Hasyim, Farida, Hukum Dagang. Jakarta: Sinar Grafika, Cet.5, April 2014

Herimanto \& Winarno, Ilmu Sosial \& Budaya Dasar. Jakarta: Bumi Aksara, Cet. 8, 2014 Irwan, Chandra, Politik Hukum Hak Kekayaan Intelektual Indonesia. Bandung: CV Mandar

Maju, Cet.1, Mei 2012

Jened, Rahmi, Interface Hukum Kekayaan Intelektual dan Hukum Persaingan. Jakarta: PT RajaGrafindo Persada, 2013. 